\title{
THE EFFECT OF GOOD CORPORATE GOVERNANCE AND FOREIGN OWNERSHIP AS A MODERATING VARIABLES ON THE BOARD INTERLOCKING ON FINANCIAL PERFORMANCE
}

\author{
Natalie Winter \\ Faculty of Business and Economics, University of Surabaya \\ nataliewinter60@gmail.com \\ Werner R. Murhadi \\ Faculty of Business and Economics, University of Surabaya \\ wernermurhadi@gmail.com \\ Mudji Utami \\ Faculty of Business and Economics, University of Surabaya \\ mudjiutami17@gmail.com
}

Received: May, 2019; Accepted: February, 2021; Published: March, 2021

DOI: https://doi.org/10.24123//mb.v20i1

\begin{abstract}
The aims of this research is to analyze the effect of number of board interlocking, board size, family board participation, board independence, control variable such as firm size, firm age, and leverage, and moderate foreign ownership to number of board interlocking towards financial firm perfomance using ROA and Tobin's $Q$ as a proxy in non financial sector companies listed in Indonesia Stock Exchange (BEI) in period 2014-2018. This research uses quantitative approach with two least square regression analysis model. The sample used in this research is firms which are listed on the non financial in Indonesia Stock Exchange (IDX) on 2014-2018 period. The number of final samples used in this study were 366 business entities with 1830 observations. The findings result of this research indicate that concurrent commissioner positions have positive and significant effect towards ROA in non financial sector companies BEI on the period 2014-2018, while independent commissioners, family of commissioners, board size, and the interaction of multiple positions of commissioners with foreign ownership have insignificant effect towards ROA in non financial sector companies BEI on the period 2014-2018. Then variables independent commissioners, board size of commissioners, and the interaction of multiple positions of commissioner with foreign ownership have positive and significant effect towards Tobin's $Q$ in non financial sector companies BEI on the period 2014-2018, while the family of commissioners and concurrent commissioner positions have insignificant effect towards ROA in non financial sector companies BEl on the period 2014-2018.

Key words: Corporate Governance, Board Interlocking, Foreign Ownership, Financial Firm Perfomance
\end{abstract}

\begin{abstract}
Abstrak
Tujuan dari penelitian ini adalah untuk menganalisis pengaruh jumlah board interlocking, ukuran dewan, partisipasi dewan keluarga, independensi dewan, variabel kontrol seperti ukuran perusahaan, umur perusahaan, dan leverage, dan kepemilikan asing yang moderat terhadap jumlah dewan yang saling terkait terhadap keuangan. kinerja perusahaan
\end{abstract}


menggunakan ROA dan Tobin's $Q$ sebagai proksi pada perusahaan sektor non keuangan yang terdaftar di Bursa Efek Indonesia (BEI) periode 2014-2018. Penelitian ini menggunakan pendekatan kuantitatif dengan model analisis regresi kuadrat terkecil. Sampel yang digunakan dalam penelitian ini adalah perusahaan yang terdaftar di non keuangan di Bursa Efek Indonesia (BEI) periode 2014-2018. Jumlah sampel akhir yang digunakan dalam penelitian ini adalah 366 badan usaha dengan 1830 observasi. Hasil temuan penelitian ini menunjukkan bahwa rangkap jabatan komisaris berpengaruh positif dan signifikan terhadap ROA pada perusahaan sektor non keuangan BEI periode 2014-2018, sedangkan komisaris independen, keluarga komisaris, ukuran dewan komisaris, dan interaksi rangkap jabatan komisaris dengan kepemilikan asing berpengaruh tidak signifikan terhadap ROA pada perusahaan sektor non keuangan BEI periode 2014-2018. Kemudian variabel komisaris independen, ukuran dewan komisaris, dan interaksi rangkap jabatan komisaris dengan kepemilikan asing berpengaruh positif dan signifikan terhadap Tobin's $Q$ pada perusahaan sektor non keuangan BEI periode 2014-2018, sedangkan keluarga komisaris dan komisaris rangkap. posisi berpengaruh tidak signifikan terhadap ROA pada perusahaan sektor non keuangan BEI periode 2014-2018.

Kata kunci: Tata Kelola Perusahaan, Board Interlocking, Kepemilikan Asing, Kinerja Keuangan Perusahaan

\section{INTRODUCTION}

As the time goes by, strong business competition requires companies to develop a good management strategy. In order to obtain sustainable performance, one of them is by implementing Good Corporate Governance. The board of directors and the board of commissioners are part of the company's internal governance. In corporate governance, there can be a board interlocking which it occurs when a board of commissioners in a company occupies a position of commissioner in another company (Chiu, Teoh, and Tian, 2013). Board interlock can be important tools companies use to evaluate specific strategies. Mol (2001) has stated that board interlocking provides boards of commissioners with wealth of experiences that serve to increase the company's competitive advantage such as valuable information about customers; suppliers; human, financial and operational resources; strategic plans and other corporate innovations in the business arena. Such business acumen contributes to the competitive advantage that companies gain and it is the primary approach for many companies to prevent environmental uncertainty. However, excessive board interlocking can undermine company performance because when viewed from the perspective of agency theory, board interlocking can result in the application of a kind of time pressure on its directors which affects the efficiency of the commissioners in monitoring company performance (Ficjh and Shivdasani, 2006).

Allam (2018) and Carlos and Luis (2011) in their research have stated that board interlocking of a company has a positive effect on company performance, this is because board interlocking provides an important channel of information and experience transfer and an active communication method to attract funds that make a positive contribution to the operational and financial performance of the company in accordance with Kaczmarek et al. (2014). On the other hand, Delci and Ilse (2016) have explained that number of board interlocking gives significant negative results, in view of more interlocks reduce the effectiveness of monitoring activities due to difficulty managing time to oversee more than one company and can reduce the company's market value.

In the research of Mike et al. (2015) and Delci and llae (2016) the board size has showed a significant positive, this is because a larger number of commissioners will bring better information because greater knowledge will help directors in making company decisions and provide more expertise, supervision. greater management, 
and access to broader resources so as to improve company performance ( Gunawan, Murhadi \& Utami, 2019; Carter et al, 2010).

In Allam's research (2018), board independence has indicated positive significance, this is because the presence of a high proportion of independent commissioners can increase effectiveness in reducing agency problems (SetiaAtmaja, Haman, \& Tanewski, 2011). However, Delci and Ilae's research (2016) have resulted in a significant negative, which means that the presence of independent commissioners does not contribute to company performance so that independent commissioners are not effective in relation to returns on invested capital.

In the research of Mike et al. (2015) family board participation has displayed a significant negative, this is because family members who serve as the board of commissioners do not have reliable abilities to manage the company. According to Smith and Amoako-Adu (1999), when the announcement of the appointment of family members to serve as the board of commissioners, the share price will decrease. This is by cause of investors think that the ability of these family members is still relatively young and lack of experiences. In Carlos and Luis's research (2011) it has a positive impact because of the large number of family members on the board of commissioners, the family can fully control decisions, policies, and the company's operations. In addition, with the presence of family members in the company, agency problems can be minimized.

This research examines the effect of corporate governance using number of board interlocking, board size, board independence, dan family board participation. This study also includes foreign ownership moderation variables that affect number of board interlocking on company performance. Control variables that is used including firm size firm age and financial leverage (Gunawan, Murhadi, and Utami, 2019).

Based on the background, the following problems are formulated: Does foreign ownership as moderating variable affect the number of board interlocking on company performance? Does the board size have a positive effect on company performance? Does board independence have a positive effect on company performance? and Does family board participation have a negative effect on company performance?

\section{RESEARCH METHOD}

The objects used in the study are Indonesian non-financial sector companies listed on the Indonesia Stock Exchange (IDX) which have audited reports for 5 consecutive years for the 2014-2018 period. The research sample was Indonesian non-financial sector companies listed on the Indonesia Stock Exchange (IDX) for the period 2014 to 2018. The sample was determined based on the following criteria: (1) non-financial sector companies listed on the Indonesia Stock Exchange for the period 2014-2018, (2) issuing financial reports which completed and had been audited regularly in the 2014-2018 period, (3) the availability of data on all necessary variables during the 2014-2018 period. Based on these criteria, a research sample of 366 companies was obtained. This study used multiple linear analysis to examine the effect of several independent and moderating variables on the dependent variable. The independent variables in this study were the concurrent position of commissioner, size of the board of commissioners, family commissioner, and independent commissioner. The moderating variables were foreign ownership and the dependent variable in the form of Return on Assets and Tobin's $Q$.

Model 1 :

$$
\begin{aligned}
\mathrm{ROA}_{\mathrm{it}}= & a+\beta_{1} \cdot I_{N T E R L}+\beta_{2} \cdot U D K_{i t}+\beta_{3} \cdot K_{I N D_{i t}}+\beta_{4} \cdot K K_{i t}+\beta_{5} \cdot F S I Z E_{i t}+ \\
& \beta_{6} \cdot F A G E_{i t}+\beta_{7} \cdot L E V_{i t}+e
\end{aligned}
$$


Model 2 :

$\mathrm{Q}_{\mathrm{it}}=a+\beta_{1} \cdot$ INTERL $_{i t}+\beta_{2} \cdot U D K_{i t}+\beta_{3}$. KIND $_{i t}+\beta_{4} \cdot K K+\beta_{5} \cdot$ FSIZE $_{i t}+$ $\beta_{6} . F A G E_{i t}+\beta_{7} \cdot L E V_{i t}+e$

Model 3 :

$\mathrm{ROA}_{\mathrm{it}}=a+\beta_{1} \cdot$ INTERL $_{i t}+\beta_{2} \cdot(\text { INTERLX FOWNER })_{i t}+\beta_{3} . U D K_{i t}+\beta_{4} \cdot$ KIND $_{i t}+$ $\beta_{5} \cdot K K_{i t}+\beta_{6} \cdot$ FSIZE $_{i t}+\beta_{7} \cdot F A G E_{i t}+\beta_{8} \cdot L E V_{i t}+\beta_{9} . F O W N E R_{i t}+e$

Model 4 :

$Q_{i t}=a+\beta_{1} \cdot$ INTERL $_{i t}+\beta_{2} \cdot(\text { INTERLX XOWNER })_{i t}+\beta_{3} \cdot U D K_{i t}+\beta_{4} \cdot$ KIND $_{i t}+$

$\beta_{5} . K K_{i t}+\beta_{6} . F S I Z E_{i t}+\beta_{7} . F A G E_{i t}+\beta_{8} . L E V_{i t}+\beta_{9} . F O W N E R_{i t}+e$

Information :

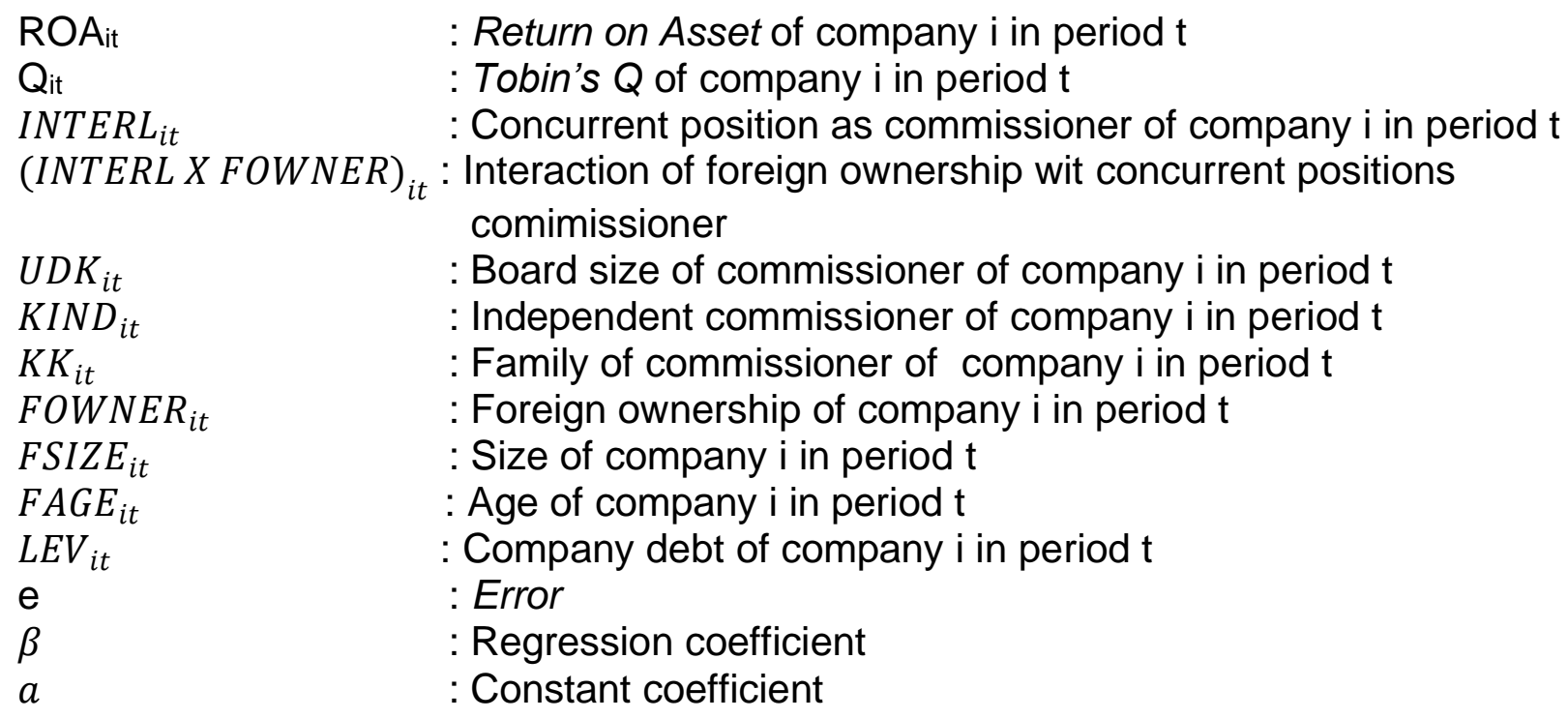

RESULT AND DISCUSSION

Table 1 shows the results of data processing for models one and three with the dependent variable is ROA.

Tabel 1. Regression results for the dependent variable ROA

\begin{tabular}{|c|c|c|c|c|}
\hline \multirow[t]{2}{*}{ Variable } & \multicolumn{2}{|c|}{ Model 1} & \multicolumn{2}{|c|}{ Model 3} \\
\hline & $\beta$ & $\mathrm{t}$ & $\beta$ & $\mathrm{t}$ \\
\hline Constant & $-0,109$ & $-1,754$ & 0,109 & $-1,749$ \\
\hline KIND & $-0,002$ & $-0,067$ & 0.002 & $-0,062$ \\
\hline $\mathrm{KK}$ & 0,002 & 0,640 & 0,002 & 0,642 \\
\hline INTERL & 0,005 & $1,932^{*}$ & 0,004 & $1,676^{*}$ \\
\hline UDK & 0,003 & 1,084 & 0,003 & 1,070 \\
\hline FSIZE & 0,004 & 1,633 & 0,004 & 1,639 \\
\hline FAGE & 0,001 & $3,597^{* \star *}$ & 0,001 & $3,583^{\star \star *}$ \\
\hline LEV & $-0,037$ & $5,943^{\star * *}$ & 0,037 & $5,942^{* \star *}$ \\
\hline FOWNER & & & 0,005 & $-0,232$ \\
\hline INTERL x FOWNER & & & 0,001 & 0,220 \\
\hline$R$ Squares & & 0,046 & & 0,046 \\
\hline Adj. R-Squared & & 0,042 & & 0,041 \\
\hline
\end{tabular}


Based on the data in table 1, it can be seen that the KIND variable has no relationship to ROA. This is supported by the research of Al-Matari et al. (2014) and Farida et al. (2010) which stated that independent commissioners have no effect on company performance based on ROA. The independent board of commissioners has no effect on company performance, this is possible because the presence of independent commissioners in the company is only a formality to fulfill regulations. The existence of independent commissioners is not to carry out a proper monitoring function and does not use their independence to oversee the policies of the directors. In addition, the minimum requirement for independent commissioners of $30 \%$ may not be high enough to cause independent commissioners to dominate the policies taken by the board of commissioners, so that independent commissioners are less effective in running the company (Farida et al., 2010).

The KK variable has no relationship to ROA. This is supported by the research of Mohammed Hasan Makhlouf et al. (2018) which explained that the family of commissioners has no effect on company performance based on ROA. The more family representatives who sit on the board of commissioners do not improve the company's performance because the competence of the board of commissioners is only standard and in supervising is less effective.

The INTERL variable has a significant positive relationship to ROA. This is supported by the research of Allam (2018) and Carlos and Luis (2011) which elaborated that concurrent commissioner positions have a significant positive effect on company performance based on ROA. This is explained in Allam (2018) which stated that the existence of multiple positions of commissioners can provide channels of information and transfer of rich experiences that serve to increase the company's competitive advantage through disclosure of information by the board of commissioners about customers, suppliers, human resources, people, finance and operations, and other corporate strategic plans and innovations, in the business arena. Board members use their reputation and personal connections to bring necessary external resources to the company. Given that the resources found in any company are limited, third parties that provide access to external resources are advantageous for the company so as to improve the company's operational performance.

The UDK variable has no relationship to ROA. This is supported by the research of Allam (2018) and Kiel and Nicholson (2003) which stated that the size of the board of commissioners has no effect on company performance based on ROA. Based on the results of several previous studies, the optimum number of a board of commissioners is seven to eight people (Jensen, 1993) or eight to nine people (Lipton and Lorsch, 1992). In the Indonesia Stock Exchange, it was found that the average size of the board of commissioners was 4.21 , which is below the optimum value. Lacking number of commissioners can lead to a lack of certain competencies and skills, which can hinder optimal decision making. These decisions that are not optimal will certainly not have any impact on company performance.

The FSIZE variable has no relationship to ROA. This is supported by the research of Simon (1962) and Whittington (1980) in Kumar and Kaur (2016) which declared that company size has no effect on company performance based on ROA. Profitability stands alone (independent) from the size of the company. This is because both large and small companies have the same opportunity to get a profit, but the size of the profits they get depends on the company's investment opportunities and opportunities in the market.

The FAGE variable has a significant positive relationship to ROA. This is 
supported by the research of Allam (2018) and Carlos and Luis (2011) which expressed that company age has a significant positive effect on company performance based on ROA. This is explained in the research of Allam (2018) and Carlos and Luis (2011) that the longer the company has been established, it means that employees or company workers have learned to be better and more efficient and have a competitive advantage in the core of their business and encourage organizational success in improving company operational performance (Arrow, 1962; Jovanonic, 1982).

The LEV variable has a significant negative relationship to ROA. This is supported by the research of Carlos and Luis (2011) which stated that debt has a significant negative effect on company performance based on ROA. This is explained in the study of Carlos and Luis (2011) that a high level of debt indicates a higher probability of bankruptcy (Jensen, 1986). The non-optimal use of debt in the company's investment financing will lead to inefficiency of the fixed costs borne by the company due to debt. In other words, the tax savings enjoyed by the company have not been matched by an increase in investment returns so that the interest cost on debt weakens the company's profitability. The large debt reflects a higher fixed expense in the form of interest costs. The amount of this interest expense will decrease the company's profit.

The FOWNER variable has no relationship to ROA. This is supported by research by Chibber and Arbor (1999) which described that foreign ownership has no effect on company performance based on ROA. The results of research conducted by Chibber and Arbor found no significant correlation between foreign ownership and company performance at ownership levels below 51\%. The result of the research showed that the average level of foreign ownership held is $13.09 \%$ in which it is lower than $51 \%$ so that foreign ownership does not affect the company's performance.

\begin{tabular}{|c|c|c|c|c|}
\hline \multirow{2}{*}{$\begin{array}{l}\text { Dependent Variable: } \\
\text { Tobins } Q\end{array}$} & \multicolumn{2}{|c|}{ Model 2} & \multicolumn{2}{|c|}{ Model 4} \\
\hline & $\beta$ & $\mathrm{t}$ & $\beta$ & $\mathrm{t}$ \\
\hline Constant & 3,917 & 3,873 & 4,034 & 3,972 \\
\hline KIND & 2,066 & $4,348^{\star \star \star}$ & 2,066 & $4,349^{\star \star \star}$ \\
\hline KK & $-0,050$ & $-0,862$ & 0,040 & $-0,687$ \\
\hline INTERL & 0,000 & 0,005 & 0.038 & $-0,878$ \\
\hline UDK & 0,103 & $2,233^{* *}$ & 0,095 & $2,066^{\star *}$ \\
\hline FSIZE & $-0,147$ & $3,940^{* \star *}$ & 0,148 & $3,932^{\star \star *}$ \\
\hline FAGE & 0,010 & $2,873^{* * *}$ & 0,009 & $2,761^{* \star *}$ \\
\hline LEV & $-0,205$ & $-2,047^{\star *}$ & 0,205 & $-2,045^{\star *}$ \\
\hline FOWNER & & & 0,424 & $-1,203$ \\
\hline INTERL x FOWNER & & & 0,196 & $2,084^{\star *}$ \\
\hline $\begin{array}{l}R \text { Squares } \\
\text { Adj. R-Squared }\end{array}$ & & $\begin{array}{l}0,023 \\
0,020\end{array}$ & & $\begin{array}{l}0,026 \\
0,021\end{array}$ \\
\hline
\end{tabular}

Table 2 shows the results of data processing for models one and three with the dependent variable Tobins $Q$. The moderator variable has no relationship to $R O A$. This is supported by research by Chibber and Arbor (1999) and Mike et al. (2015) which explained that the moderator has no effect on company performance based on ROA. From the results of the research conducted, the moderation variable that belongs to the classification of potential moderation in which the foreign ownership 
variable and the interaction between multiple positions of commissioner and foreign ownership are not significant to ROA, so that foreign ownership variables do not moderate the dual position of commissioner to ROA. In statistical data, the variable of foreign ownership is only $13.09 \%$, which means that the role of foreign investors is not enough to make the commissioners who are concurrent improve company performance. This is because foreign investors lack of power to make the members of the board of commissioners progressing, in transferring their experience and information to the company, so that it does not strengthen the influence on company performance.

Based on data in Table 2 can be identified KIND variables have a significant positive relation to Tobin's $Q$. This is supported by research Allam (2018) which stated independent directors provide significant positive effect on the performance of companies based on Tobin's $Q$. Independent commissioners contribute effectively to company management by maintaining different perspectives and representing stakeholders. Companies with independent commissioners will produce better performance than other companies without independent commissioners, because independent commissioners are able to supervise and control the company's internal operations through the application of supervisory authority. A larger proportion of independent commissioners can improve management control more effectively, alignment between managers and shareholders, and company performance (Ertimur et al., 2010).

The KK variable has no relation to Tobin's $Q$. This is supported by research Tri Puput Komalsari and Muhammad Alfin Nor (2014) which stated the family commissioners does not effect on the performance of companies based on Tobin's $Q$. This can be seen from Table 4.2 shows that the average family of commissioners from the study is only 0.6208 or less than 1 , which means that most companies in Indonesia do not have members of the board of commissioners, thus family of commissioners is less able to influence the value of the company.

The INTERL variable has no relation to Tobin's $Q$. This is supported by the research of Omer et al. (2013) which explained that duplicate the commissioners had no effect on Tobin's $Q$. This shows that the commissioners who concurrently have an information channel and the transfer of experience that more or less influences the decisions in a company. According to Law Number 40 of 2007 concerning Limited Liability Companies, article 108 paragraph 4 states that the board of commissioners consists of more than 1 (one) member as an assembly and each member of the Board of Commissioners cannot act individually, but based on the decision of the Board of Commissioners. As a result, the information provided by the commissioner cannot influence the decisions of other board members and will not affect firm value.

The UDK variable has a significant positive relationship to Tobin's $Q$. This is supported by research Vincent and Nicole (2010) which elaborated that the size of the board of commissioners significant positive effect on Tobin's $Q$. The more the number of commissioners in the company, the better, because the more people monitor the behavior of management so that they will always act according to the wishes of shareholders (Dalton, 1999). The more the board of commissioners, the more input to the board of directors, so that the options obtained by the board of directors are more and more. Therefore, increasing the number of commissioners can improve company performance (Dalton et al., 1999 in O connel, 2010).

The FSIZE variable has a significant negative relation to Tobin's $Q$. This is supported by research Haniffa \& Hudaib (2006) in Darmadi (2013) which said that the size of the company's significant negative effect on Tobin's $Q$. This is explained in the research of Haniffa \& Hudaib (2006) in Darmadi (2013) that larger companies can 
cause inefficiency which results in poor company performance (Klapper \& Love, 2004). In addition, large companies are under the control of managers who pursue their own interests and therefore maximizing profits as a function of company objectives is replaced by a function of maximizing managerial interests so that it has a negative impact on the company (Pervan \& Visic, 2012).

The FAGE variable has a significant positive relationship to Tobin's $Q$. This is supported by studies Cecilia Audrey (2018) which described that the age of the company significant positive effect on Tobin's Q. This is elaborated by Kartika (2009) in Efriana Mustika (2012) that the more established or mature the company, the better the company's performance. In which, investors have a positive perspective on the company that an established company is able to survive through economic fluctuations and market conditions.

The LEV variable has a significant negative relation to Tobin's $Q$. This is in line with the research of Fosu Samuel et al. (2016) which explained that the debts significant negative effect on Tobin's $Q$. This is written in the research of Fosu Samuel et al. (2016) stated that the bigger the debt, the bigger the investment risk. The high debt ratio shows that the company is not solvable, which means that its total debt is greater than its total assets (Van Horne, 1997). Debt is a ratio that calculates how far the funds provided by creditors are also a ratio that calculates how far investors see a company with high assets but high leverage risk, so they will think twice about investing in the company, because it is feared that high assets will be obtained. of debt will increase investment risk if the company is unable to pay off its obligations on time.

Variable FOWNER has no relation to Tobin's Q. This is supported by research Chibber and Arbor (1999), which states that foreign ownership does not give effect to the performance of the company based on Tobin's $Q$. The results of research conducted by Chibber and Arbor found no significant correlation between foreign ownership and company performance at ownership levels below $51 \%$. The results showed that the average level of foreign ownership held was $13.09 \%$, which means it was lower than $51 \%$ so that foreign ownership had no effect on firm value.

Variable moderator has a significant positive relationship to Tobin's $Q$. This is supported by research of Artha Vijnana (2017) which stated moderator gives significant positive effect on the performance of companies based on Tobin's Q. From the research conducted, moderating variables held including the classification of authentic moderation where the variable of foreign ownership is not significant to Tobin's $Q$ and interaction between concurrent position as commissioner with foreign ownership significant to Tobin's $Q$, so that foreign ownership moderate double position as commissioner on ROA. Foreign ownership directly affects the position of commissioner and firm value. This is due to the presence of foreign investors also contributes to monitoring the management of the company, especially for commissioners who have multiple positions in other companies, thus it creates a pressure on management to serve stock interests. Companies with interlock status are also empirically proven to have good financial performance, in this way it has an impact on investor confidence, and it is hoped that market performance will improve because investors put trust on the reputation of the board of commissioners (Anderson and Reeb, 2003).

\section{CONCLUSION}

Based on the results of hypothesis testing using the test (partial), it can be seen in model 1 and model 3 that the double position variable of commissioners and company age has a significant positive effect on ROA, the debt variable has a 
significant negative effect on ROA, the independent commissioner variable, the family of commissioners, the board size of commissioners, company size, foreign ownership, and interaction between multiple positions of commissioner and foreign ownership (moderation) have no effect on ROA. Based on the results of hypothesis testing using the t test (partial), it can be concluded in model 2 and model 4 that the independent commissioner variable, the size of the board of commissioners, the age of the company, and the interaction between multiple positions of commissioner with foreign ownership (moderation) have a significant positive effect on Tobin's $Q$, the variable size of the company and debts significant negative effect on Tobin's $Q$, family variables commissioner, double that of the commissioners, and foreign ownership has no effect on Tobin's $Q$.

This study has limitations, those are the year and several research variables used. For further research, it is expected to be able to do the research based on newer years and increase the number of variables.

\section{REFERENCES}

Al-Matari EM, Al-Swidi A, BtFadzil F. (2014). The Effect on the Relationship Between Board of Directors Characteristics on Firm Performance in Oman: Empirical Study. Middle-East Journal of Scientific Research. 21(3): 556-574.

Arrow K. (1962). The economic implications of learning by doing. Review of Economic Studies. 29: 155-173.

Audrey C. (2018). Pengaruh Struktur Modal Terhadap Nilai Perusahaan dengan Ukuran dan Umur Perusahaan sebagai Variabel Moderator (Studi Kasus Tahun 2014-2016) pada Perusahaan Sub-Sektor Makanan dan Minuman yang Terdaftar di BEl. Diponegoro Journal of Social and Politic. 1-16.

BPK: Badan Pemeriksa Keuangan. (2007). Undang-Undang No. 40 tahun 2007 tentang Perseroan Terbatas. Jakarta: Badan Pemeriksa Keuangan.

Chibber PK, Majumdar S. (1999). Foreign ownership and profitability : property rights, control and the performance of firms in India Industry. Journal of Law and Economics. 26(3): 209-238.

Dalton D, Daily C, Johnson J, Ellstrand A. (1999). Number of directors and financial performance: A meta-analysis. Academy of Management Journal. 42: 674-686.

Darmadi I. (2013). Analisis Faktor yang Mempengaruhi Manajemen Pajak dengan Indikator Tarif Pajak Efektif. Diponegoro Journal of Accounting. 2(4): 1-12.

Dede Asis Negara. [Cited in 2019 November 10]. Available from http://magisteredu.blogspot.com/2015/04/model-regresi-moderasi-moderated.html?m=1

Eliezer M. Fich Anil Shivdasani. (2006). Are Busy Boards Effective Monitors?. The Journal of Finance. 61(2): 689-724.

Ertimur Y, Ferri F, Stubben S. (2010). Board of directors' responsiveness to shareholders: Evidence from shareholder proposals. Journal of Corporate Finance. 16(1): 53-72.

Farida YN, Prasetyo Y, Herwiyanti E. (2010). Pengaruh Penerapan Corporate Governance terhadap Timbulnya Earnings Management dalam Menilai Kinerja Keuangan pada Perusahaan Perbankan di Indonesia. Jurnal Bisnis dan Akuntas. 12: 69-80.

Fosu S, Danso A, Ahmad W, Coffie W. (2016). Information asymmetry, leverage and firm value: Do crisis and growth matter? International Review of Financial Analysis. 46: 140-150.

Gunawan, C., Murhadi, W.R. \& Utami, M. (2019). A Study on the Effects of Good Corporate Governance - Gender Diversity on the Company Performance. Advance in social science, education and humanities research 308: 32-35.

Hamdan A. (2018). Board Interlocking and Firm Perfomance : the Role of Foreign Ownership in Saudi Arabia. International Journal of Managerial Finance. 14(3): 266-281.

Horne JCV, John MW. (1997). Prinsip-Prinsip Manajemen Keuangan. Jakarta: Salemba empat.

Jensen M. (1993). The Modern Industrial Revolution, Exit, and the Failure of Internal Control 
Systems. Journal of Finance. 48(3): 831-880.

Jensen M. (1986). Agency costs of free cash flow, corporate finance, and takeovers. American Economic Review. 76: 323-329.

Jovanonic B. (1982). 'Selection and the Evolution of Industry'. Econometrica. 50: 649-670.

Kiel GC, Nicholson GJ. 2003. Boards that Work: A New Guide for Directors. Sydney: McGraw Hill.

Klapper L, Love I. (2004). Corporate governance, investor protection, and performance in emerging markets. Journal of Corporate Finance. 10 (5): 703-723.

Komalasari P, Nor M. (2014). Pengaruh Struktur Kepemilikan Keluarga, Kepemimpinan dan Perwakilan Keluarga terhadap Kinerja Perusahaan. Jurnal Akuntasi. 5(2): 133-150.

Kumar N, Kaur D. (2016). Firm Size and Profitability in Indian Automobile Industry: An Analysis. Pacific Business Review International. 8(7): 69-78.

Lipton M, Lorsch J. (1992). A modest proposal for improved corporate governance. Business Lawyer. 48: 59-77.

Makhlouf M, Laili N, Ramli N, Al-Sufy F, Basah M. (2018). Board of Directors, Firm Perfomance and the Moderating Role of Family Control in Jordan. Academy of Accounting and Financial Studies Journal. 22(5).

Omar T, Shelley M, Tice F. (2014). Do Well-Connected Directors Affect Firm Value?. Journal of Applied Finance. (2): 1-15.

Peng MW, Mutlu CC, Sauerwald SAKY, Wang DY. (2015). Board Interlocks and Corporate Perfomance Among Firms Listed Abroad. Journal of Management History. 21(2): 257282.

Pervan, M. and Visic, J. (2012) Influence of Firm Size on Its Business Success. Croatian Operational Research Review (CRORR), 3, 213-223.

Pombo C, Gutierrez LH. (2011). Outside Directors, Board Interlocks and Firm Perfomance : Empirical Evidence From Colombian Business Groups. Journal of Economics and Business. 63: 251-277.

Roszaini Haniffa Mohammad Hudaib. (2006). Corporate Governance Structure and Performance of Malaysian Listed Companies. Journal of Business Finance \& Accounting. 33(7-8): 1034-1062.

Ronald C. Anderson David M. Reeb. (2003). Founding-Family Ownership and Firm Performance: Evidence from the S\&P 500. The Journal of the american finance association. 58(3): 1301-1328. https://doi.org/10.1111/1540-6261.00567

Setia-Atmaja, Lukas, Haman, Janto and Tanewski, George. (2011). The role of board independence in mitigating agency problem II in Australian family firms. British accounting review. 43(3): 230-246, doi: 10.1016/j.bar.2011.06.006.

Vesco DG, Beuren IM. (2016). Do the Board of Directors Composition and the Board Interlocking Influence on Performance ?. BAR, Rio de Janeiro. 13(2).

Vijnana A. (2017). The Relationship between Foreign Ownership and Firm Performance in India: An Empirical Analysis. 59(2): 152-162.

Vincent O, Nicole C. (2010). The relationship between firm performance and board characteristics in Ireland. European Management Journal. 28(5): 387-399. 


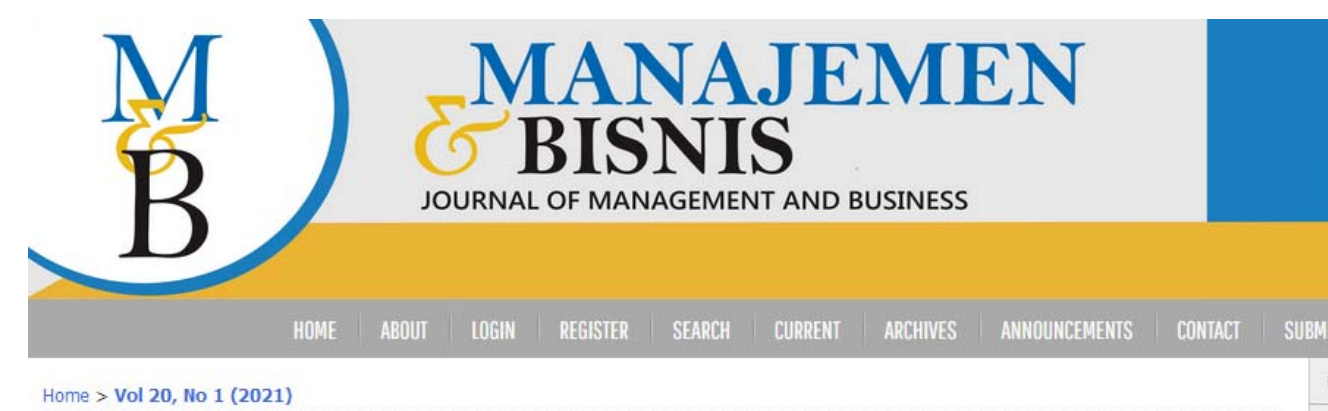

Journal of Management and Business

Manajemen \& Bisnis (MABIS) is an open access journal with ISSN 1412-3789 and e-ISSN 2477-1783. The editorial board invites authors and experts to publish and share their ideas through scientific and

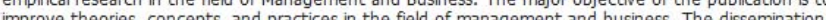
hprove the findings. We are going to be a bridge between theories and practices in management and business.

The paricipan of the wellknown international and national experts in the editorial board is a

The participation of the well-known international and national experts in the editorial board is a guarantee of the sustainability and quality of the publications as a contribution to the development semi annual (March and September) and contained ten empirical researches, preferably in English. This wir make it possble to introduce the latest empincal research findings to practitioners and t researchers, lecturers, undergraduate and postgraduate students, and also practitioners.
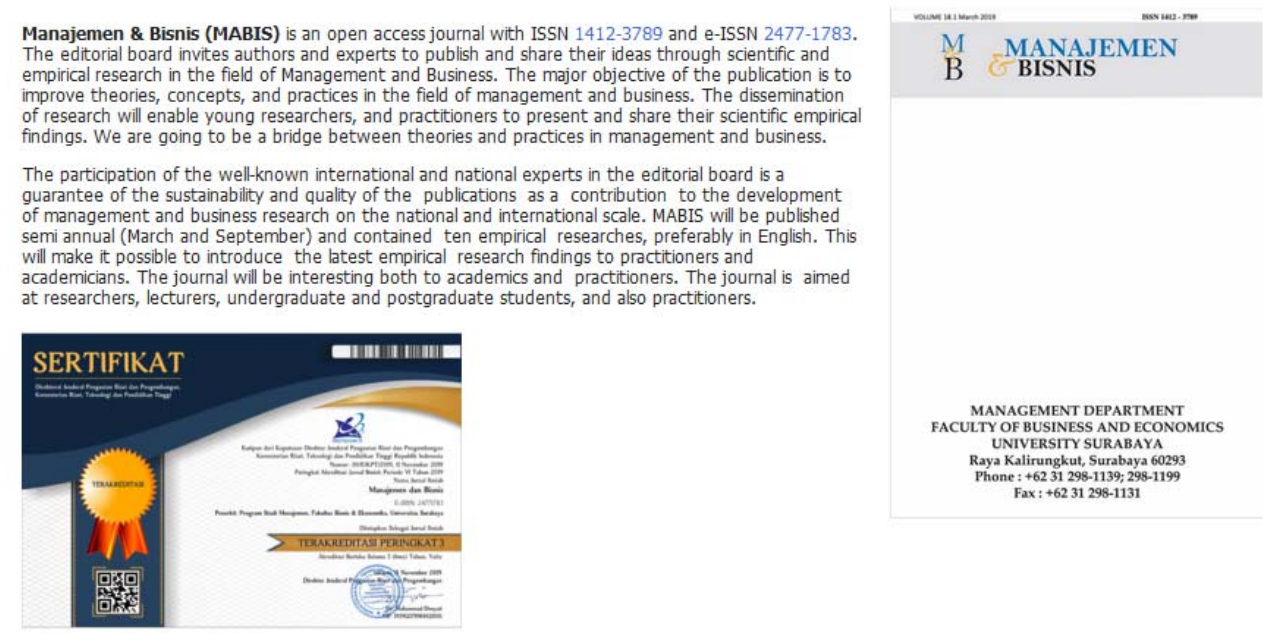

ISSN: $1412-3789$

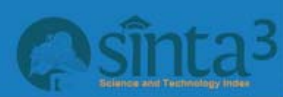

Manajemen $\&$ Bisnis (MABIS) has been accredited as a scientific journal by the Ministry of ResearchTechnology and Higher Education Republic of Indonesia: No. 30/E/KPT/2019

\begin{tabular}{|l|}
\hline Ethics Statement \\
\hline Editorial Team \\
\hline Reviewer Acknowledgment \\
\hline Focus and Scope \\
\hline Publishing System \\
\hline Author Guidelines \\
\hline Visitor Statistics \\
\hline OPEN JOURNAL SYSTEMS \\
\hline USER \\
Username \\
Password \\
\hline Remember me \\
\hline Login \\
\hline JOURNAL CONTENT \\
\hline Search \\
\hline Search SCOPe \\
\hline All \\
\hline Search \\
\hline
\end{tabular}




\section{Editorial Team}

\section{Chief of Editor}

Dr. Erna Andajani, S.T., M.M., Faculty of Business and Economics. Universitas Surabaya, Indonesia

\section{Managing Editor}

Dr. Putu Anom Mahadwartha, Faculty of Business and Economics. Universitas Surabaya, Indonesia, Indonesia

Dr. Werner R. Murhadi, Faculty of Business and Economics. Universitas Surabaya, Indonesia, Indonesia

Dr. Dudi Anandya S.T., M.Si., Faculty of Business and Economics. Universitas Surabaya, Indonesia, Indonesia

Dr. Noviaty Kresna Darmaetiawan, S.Psi., M.Si., Faculty of Business and Economics. Universitas Surabaya, Indonesia, Indonesia

\section{(c) (7)}

This work is licensed under a Creative Commons Attribution 4.0 International License. ISSN: 1412-3789. e-ISSN: $2477-1783$.

\section{Asinta Google Cि GARUDA \\ 00126966}




\section{Vol 20, № 1(2021): MARCH 2021}

\section{Table of Contents}

\section{Articles}

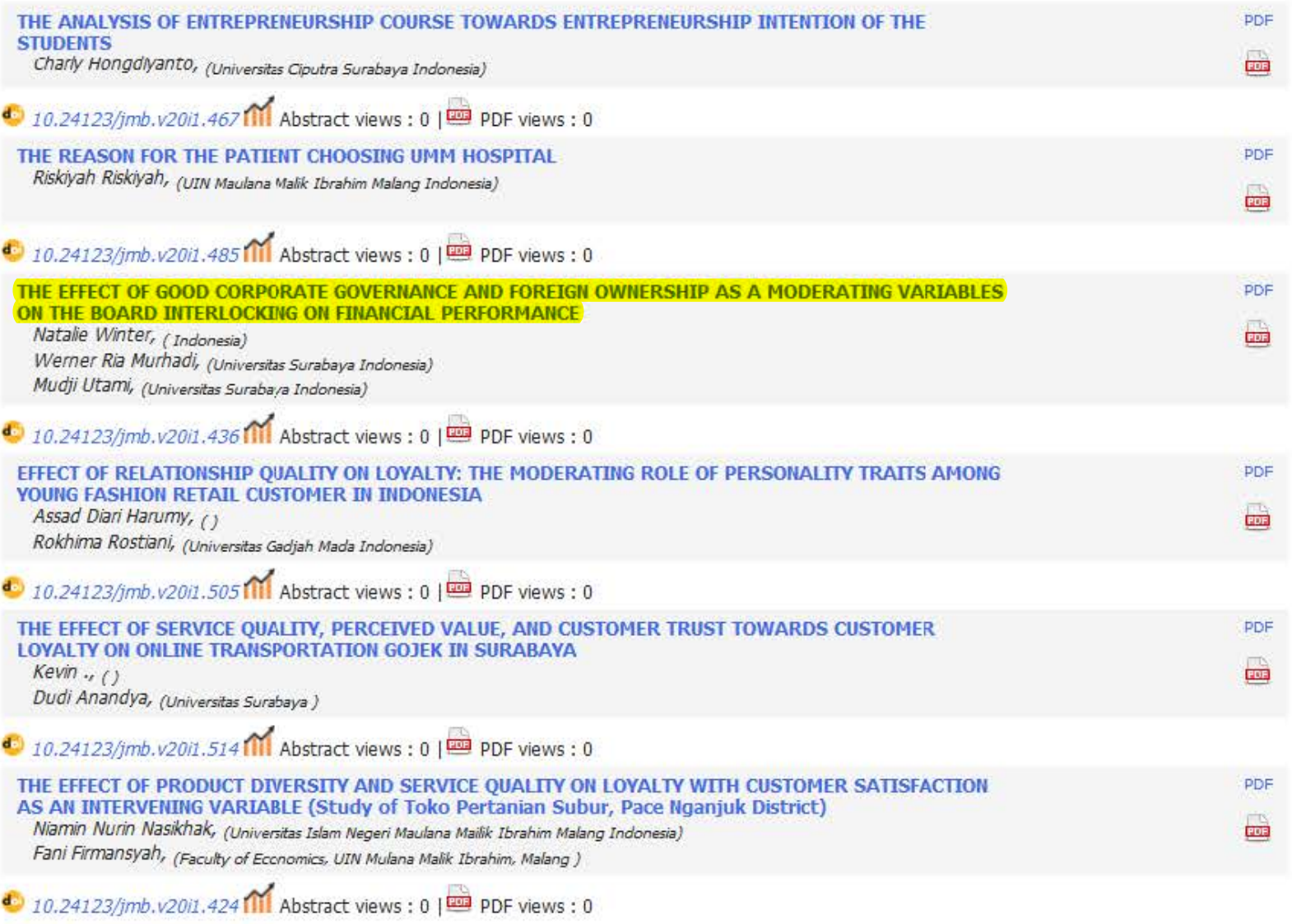

